\title{
One Chrysidid Wasp, Holopyga generosa, New to Korea
}

\author{
Seong Ho Bang, Hyeong Hwa Ha, Jeong-Kyu Kim* \\ Department of Biological Sciences, Faculty of Science, Hanseo University, Seosan 356-707, Korea
}

\begin{abstract}
The Korean occurrence of Holopyga generosa (Förster, 1853) is reported here for the first time. The genus is also new to Korea. This species might be easily distinguished from other Holopyga species by its relatively long hairs on the head and mesosoma. Diagnosis and digital images are provided.
\end{abstract}

Keywords: Chrysididae, Holopyga, generosa, Korea

\section{INTRODUCTION}

The genus Holopyga consists of 91 extant species from all zoogeographic regions, but is mainly distributed in the European part of the Palaearctic region (Agnoli and Rosa, 2011). The biology of this genus is poorly known, except for the parasitoids of ground-nesting sphecid wasps and the bee genus Chalcicodoma (Linsenmaier, 1959; Kimsey and Bohart, 1990).

Of the tribe Elampini, this genus can be distinguished by the following combination of characteristics: extended and angulate postocular region (Fig. 1B), compactly cross-ridged scapal basin (Fig. 1C), presence of inter-ocellar sulcus and genal carina, strongly arched forewing medial vein and setose medial cell (Fig. 1D), presence of an anteromedial pit on the pronotum, angulate mesopleuron, evenly rounded apical margin of tergum III (Fig. 1A), subbasally angulate fore femur with ventral carina, multidentate tarsal claws, and vosella with digitus and cuspis (Fig. 1E).

In this study, we report an occurrence of Holopyga generosa (Förster, 1853) in Korea for the first time, and the diagnosis and digital images are presented. The genus is also new to Korea.

Morphological terminology used followed Kimsey and Bohart (1990). All measurements were taken at the maximal portion of the structure being measured. Body length was measured from the anterior margin of the head to the posterior margin of the metasoma.

All the examined specimens are housed in the Laboratory of Insect Diversity of Hanseo University.

\section{SYSTEMATIC ACCOUNTS}

Order Hymenoptera

Family Chrysididae

Subfamily Chrysidinae

Tribe Elampini

Genus Holopyga Dahlbom

Holopyga Dahlbom, 1845: 4. Type species: Holopyga amoneula Dahlbom (designated by Ashmead, 1902: 227).

\section{Holopyga generosa (Förster, 1853)}

Ellampus generosa Förster, 1853: 349, ð7, Germany Nach, Aachen (Mus. Berlin).

Material examined. Korea: 1 우, Daejeon-si, Seo-gu, Doandong, 1 Jul 1992, Bak YS; 1 우, Gyeongbuk, Gyeongsan-si, Dae-dong, Yeongnam Univ. campus, 2 Jun 1995, Mun HJ; 1 우, Gangwon-do, Wonju-si, Maeji-ri, Yonsei Univ. campus, 14 Jun 1996, Byun HW; 1 ऽ, Mt. Gyeongsusan, 4-5 Jun 1997 (collector not written); 1 ऽ , Jeongeup-si, Jangseong-gun, Bukha-myeon, Baekhak-dong, 20 May 2005, Chung DK.

Description (female). Body 7.0-7.4 mm long, and forewing 4.5-5.4 mm long (Fig. 1A, B). Head and mesosoma with somewhat dense, long (especially ones in frons and pronotum twice as long as the diameter of anterior ocellus), whitish hairs, but hairs on metasoma shorter.

Coloration (Fig. 1A): Frons, scutum, scutellum and lateral part of propodeum bluish green with partly violet. Antennal scape, pedicel, pronotum, mesopleuron, metapleuron, pro- (c) This is an Open Access article distributed under the terms of the Creative Commons Attribution Non-Commercial License (http://creativecommons.org/ licenses/by-nc/3.0/) which permits unrestricted non-commercial use, distribution, and reproduction in any medium, provided the original work is properly cited.

\footnotetext{
*To whom correspondence should be addressed

Tel: 82-41-660-1349, Fax: 82-41-688-3403

E-mail: kwasp@hanseo.ac.kr
} 

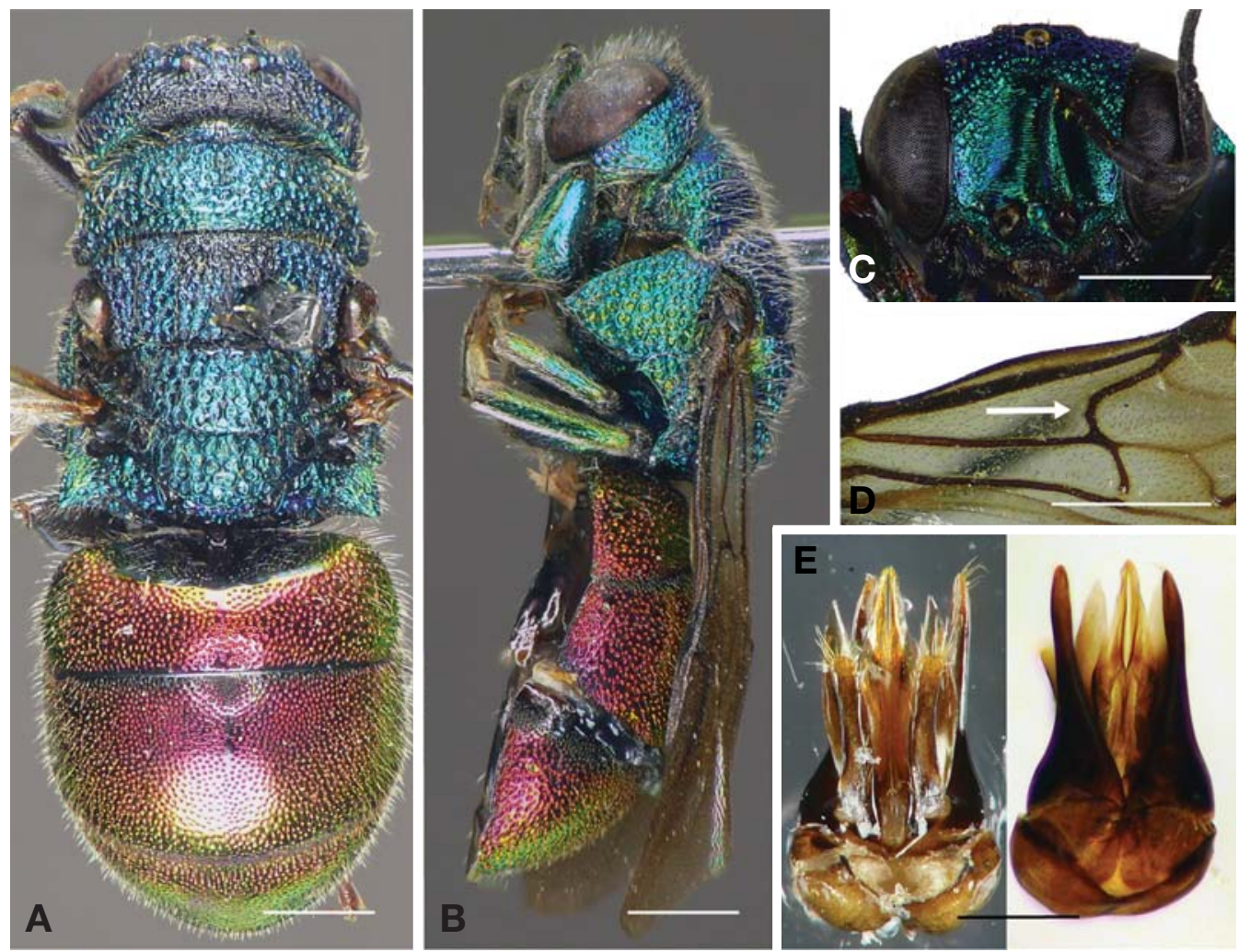

Fig. 1. Holopyga generosa (Förster). A, General habitus, dorsal; B, General habitus, in profile; C, Head, in frontal view, with palpal basin; D, Part of forewing showing strongly arched medial vein (arrow); E, Genital capsule, ventral (left), dorsal (right). Scale bars: $A-D=1 \mathrm{~mm}, E=0.5 \mathrm{~mm}$.

podeum, femora, and outside of tibiae green with partly violet and blue. However, larger median part, of vertex, occiput and median (area between notauli) anterior half of scutum black. Metasomal tergum I reddish gold with partly black, and terga II-III reddish gold without any black marking. Sterna black.

Head: Slightly transverse, in frontal view, ca. $1.3 \times$ as broad as long; seen from above, ca. $2.5 \times$ as broad as long. Scapal basin somewhat deeply concave and densely carinate (Fig. 1C). Antennal flagellum I ca. $2.7 \times$ as long as broad at apex, and ca. $2.0 \times$ as long as flagellum II. Frons except for scapal basin and vertex reticulate; occiput densely punctate. Larger median part of clypeus with dense large punctures, but subantennal space with sparse punctures. Gena reticulate and carinate.

Mesosoma: Pronotum densely punctate, but partially reticulate, ca. $2.3 \times$ as board as long; anteromedial pit longitudinally linear in shape. Scutum, almost same as pronotum in length, reticulate, but anteromedial black area with dense small punctures. Scutum, mesoplueron, scutellum, metanotum and propodeal posterior face closely reticulate. Apical twothirds lower inner marginal part of mid femur depressed and polished. Tarsal claw with four (including basal tiny tooth) subsidiary teeth.

Metasoma: Anterior sloping face of tergum I with moderate small punctures and longitudinal carinae; uppermost area of anterior sloping face with transverse impunctate smooth band; horizontal face of tergum I with dense medium-sized punctures. Tergum II with median longitudinal smooth line in its basal half. Dorsal faces of terga II-III with moderate large punctures, but dense larger punctures in their lateral parts.

Male. Much as in female, but different in the following details. Body length $7.4 \mathrm{~mm}$, and forewing length $5.3 \mathrm{~mm}$ in two specimens herein. Head and mesosoma somewhat more purplish. Hairs on sterna longer than ones in female. Genitalia as in Fig. 1E showing typical genital capsule structure of Holopyga species (see Kimsey and Bohart, 1990; Arens, 2004), with following characteristics: aedeagus spearhead-like, aedeagal lobes almost touching each other (not strongly departed), tip of aedeagus slightly exceeding gonostyle end, and digitus relatively broad.

Distribution. Transpalearctic: North Africa, Europe, Middle East, China, Korea (new record).

Remarks. This species might be easily distinguished from 
other Holopyga species by its relatively long hairs on the head and mesosoma. The taxonomic status of this species is very complicated. Since its original establishment by Förster (1853), this species was considered to be a mere synonym of Holopyga chrysonata (Kimsey and Bohart, 1990), or was down-graded to a subspecies of $H$. fastuosa (Linsenmaier, 1997). However, Agnoli and Rosa (2011) re-elevated it as a valid separate species. Concerning the taxonomic status of this form in this study, we adopted the opinion of Agnoli and Rosa (2011), who reflected the most comprehensive and recent results.

\section{ACKNOWLEDGEMENTS}

This study was supported by the Korean Ministry of Environment (the Project of the Survey of Korean Indigenous Species, NIBR).

\section{REFERENCES}

Agnoli GL, Rosa P, 2011. Holopyga generosa (Förster, 1853)

[Internet]. Chrysis.net, Database of the Italian Chrysididae, interim version 5, Accessed 16 Sep 2011, <http:// www. chrysis.net/database>.

Arens W, 2004. Revision der Gattung Holopyga auf der Peloponnes mit Beschreibung zweier neuer Arten (Hymenoptera; Chrysididae). Linzer Biologische Beiträge, 36:19-55.

Ashmead WH, 1902. Classification of the fossorial, predaceous and parasitic wasps, or the superfamily Vespoidea. The Canadian Entomologist, 36:281-285.

Dahlbom AG, 1845. Disposito methodica specierum Hymenopterum, secundum Insectorum naturales. Berlingianis, Lund, pp. 1-20.

Förster A, 1853. Eine Centurie neuer Hymenopteren. Verhandlungen des Naturhistorischen Vereines der Preussischen Rheinlande, 10:266-362.

Kimsey LS, Bohart RM, 1990. The chrysidid wasps of the world. Oxford University Press, Oxford, pp. 1-649.

Linsenmaier W, 1959. Revision der Familie Chrysididae. Mitteilungen der Schweizerischen Entomologischen Gesellschaft, 32:1-232.

Linsenmaier W, 1997. Altes und Neues von den Chrysididen (Hymenoptera, Chrysididae). Entomofauna, 18:245-300.

Received October 10, 2011

Revised November 7, 2011 Accepted November 14, 2011 